\title{
Towards a codification of practical knowledge
}

Géraldine Rix ${ }^{1}$, Pascal Lièvre ${ }^{2}$

${ }^{1}$ UFR STAPS, Blaise Pascal University, Clermont-Ferrand, France

Correspondence: Geraldine Rix, UFR STAPS, BP 104, 63172 Aubière Cedex, France

E-mail: Geraldine.rix@univ-bpclermont.fr

2 IUP de Management of Clermont-Ferrand, University of Auvergne, Clermont-Ferrand, France

Correspondence: Pascal Lièvre, IUP de Management, Pôle tertiaire, BP 304, 63008 Clermont-Ferrand Cedex 1, France

E-mail: PascalLievre@wanadoo.fr 


\begin{abstract}
:
As practical knowledge seems to have a central place in organisational issues, we focus on possibilities to study and formalize it. From an unusual theoretical perspective, we view practical knowledge as embodied knowing which only is only manifest through action in a particular situation. Although this knowledge is largely implicit, we try to make what is 'articulable' explicit. After highlighting the stakes involved in the codification of practices, we review the ontological and epistemological assumptions underlying the method developed. It is founded on participant observation, a video recording of a situated subjective perspective and an ex post interview using this perspective to aid an actor to make part of his/her practical knowledge explicit. We present its implementation within research on polar expeditions in order to understand how an experienced actor deals with risks. In conclusion, we point out (1) the importance of this kind of data in knowledge management, (2) some lines of further research.
\end{abstract}

Key-words: Case study, knowledge management tools, reflective practice, tacit knowledge, codification, knowing-in-action

Running title: Codifying practical knowledge 
Following Polanyi's theses (1996) and as several other authors have noted (Brown \& Duguid 1991; Cook \& Brown 1999; Nonaka \& Tackeuchi 1995; Orlikowski 2002; Schön 1983; Tsoukas 1996), we have questioned practical knowledge and its central place in organisational issues (Foray 2004; Tsoukas 2003). In spite of the many developments concerning knowledge management in different kinds of organisation, there are very few methodological propositions to approach knowledge systems and processes (Patriotta 2004). Without dealing with this whole question, we focus on practical knowledge in the context of its production and on possibilities to study and formalize it. In this way, we try to make a methodological contribution to knowledge management both for researchers and practitioners. This contribution is rooted in unusual theoretical references: whereas "Polanyi (1966) is by tradition the authoritative source for the concept [of tacit knowledge]" (Gourlay 2006, p.60), we refer also to Piaget (1974). His propositions enable us to view practical knowledge differently, its tacitness, and to understand how it can, to some degree, be articulated. Practical knowledge is, thus, conceived as "connaissances-en-acte" or knowing-in-action. Knowing-in-action is viewed as embodied knowing which only manifests itself in by, and during action in a particular situation. Although this knowledge is largely implicit, we try, through the method, to make what is 'articulable' explicit (Yanow \& Tsoukas 2007, p.10). In this way, following Vermersch's phenomenological perspective (1999a, 2003), we attempt to approach the actor's own situated perspective.

After highlighting the stakes involved in the codification of practices, we review the ontological and epistemological assumptions of the method. Then, we present the conditions of its implementation. What follows next is an empirical example, adaptation practices in a polar expedition, in order to illustrate the method. In conclusion, we highlight on the one hand, the importance and the use of this kind of data in knowledge management, on the other, we point out the limits of such results and directions of further research.

\section{Knowledge management and challenges of codification of practices}

The codification of practices begins with writing. According to Goody (1977), this operation expresses a society's will to make up for the weaknesses and uncertainties of human memory with the aim of storing knowledge, perceived as a learning program. But writing also has cognitive effects on society, by developing capacities for abstraction and the critical function, which play a specific role in encouraging new knowledge production. This operation takes on a particular value today in relation to the emergence of a knowledge-based economy (Foray 2004). The key factors for the success of companies and national economies are more than 
ever dependent on their capacities to produce and use knowledge. Since the main source of this knowledge is tacit -as the concept of "tacit knowledge" carries many meanings (Gourlay 2006), we later explain how we define it-, the problem of codification becomes vital in economic terms. In effect, codification makes it possible to detach knowledge from the person who possesses it (Myers, in Gourlay 2006). It involves a fixed cost -that of expressing the knowledge in a language and its recording on a support- but then seems to increase the efficiency of a whole series of knowledge management operations: memorization, distribution, learning. Once a formula has been written, which may represent a significant fixed cost, it may then be communicated at a negligible marginal cost. In the management field, Nonaka \& Takeuchi (1995) have identified a key stage in the spiral of organisational knowledge creation, the spearhead of Japanese company performance: the stage known as externalization. It consists of the passage from tacit knowing to explicit knowledge. The codification of tacit knowing has become a challenge for both economists and managers. At the same time, it is a complex operation, due to the very nature of tacit knowing, which it still seems impossible to reduce to a codification operation. In addition, the codification process can never supply all the knowledge necessary to undertake an action.

In pragmatic terms, companies that have undertaken knowledge management have found this problem a stumbling block at some point in the process. Two ways of envisaging knowledge management, two kinds of knowledge management strategies have been identified (Hansen et al. 1999): a codification strategy where knowledge is codified and stored in databases, and a personalization strategy where personal interaction is essential. These two forms of knowledge management reflect different visions of the organisation -on the one hand, the paradigm of Herbert Simon's information processing system, and on the other, the community of practice of Lave \& Wenger. The first is based on a conception of knowledge management in information system terms, a cognitivist vision: we can take the image of a physical platform for storage of information; the second treats knowledge management in terms of the management of human resources, a communitarist vision: we can take the image of the social network. The codification operation is as essential to the first strategy as it is negligible or even non-existent in the second. Rather than completely contrasting these two forms of management, many authors try to combine them. We may well ask whether we are not actually in the presence of two socio-technical configurations (Latour 2005), that we must describe effectively: what is a data warehouse without the people who use it? What is a social network that operates without any physical support? The operation of codification takes different forms, depending on the socio-technical pairing modes applied. Lastly, we can 
envisage within a community of practice that mentoring between an expert and a novice is based, at a given moment in time, on the expert's expression of his/her practice, taking the form of a written discourse which the novice will use as a support within the framework of his/her learning.

As the codification of practices seems to become a knowledge management tool, we have developed a method in order to study and formalize knowing-in-action.

\section{Methodological presuppositions}

In order to outline how we try to study and formalize practical knowledge, it is necessary to specify several postulates underlying the method. First, we claim that practice is embedded in its context. Referring particularly to the ethnomethodological theses of Garfinkel (1967) and of De Fornel \& Quéré (1999), to the notions of situated action (Suchman 1987), and of distributed cognition (Hutchins 1995), we assert that action is not dissociable from situation, nor from cognition: it is impossible to understand the practice outside of its local setting. As suggested by Suchman (1987) and Orr (1996), we must study effective and singular actions, their courses in a particular physical and human framework, and what underlies each one. Generic principles, if needed, are established, a posteriori, by the researcher from work previously carried out on different actions which have been undertaken and understood as such Consequently, the studies are not directly aiming for generalities or rules that actors produce to account for their usual activity. Yet, 'as several anthropologists, including Suchman (1987) and Bourdieu (1972) point out, "informants" often describe their jobs in canonical terms though they carry them out in non-canonical knowledge' (Brown \& Duguid 1991, p 42). In the tradition of ethnological research, activity is thus apprehended in a usual situation, in the way it was done, and in its singularity - and not only through the actor's discourse. The fact of not experiencing the practice directly hinders the study (Orlikowski 2002). The practice is thus studied in its ordinary context (Garfinkel 1967). We are not concerned here with denying that the researcher participates in the situation which he/she studies - it is for this reason that we do not use the term natural. Rather, we point out that the researcher is interested in an actual activity, not in an experimental framework, and in the usual life context of the actors concerned, which is set apart from the presence of the researcher. We therefore describe an ordinary as opposed to an extra-ordinary context which strays from what the actors are confronted with in a routine situation.

The second postulate breaks with the ethnomethodological theses discussed above and those of Bourdieu (1972). For us, understanding a practice cannot be limited to the 
observation of behaviour, but presupposes the understanding of significant underlying facets. From a phenomenological perspective, Vermersch (2004, p.36) provides a quote that enlightens our understanding of Merleau-Ponty's The Structure of Behaviour (1942): action seems to be 'a double-sided object, one public and behaviourally observable, the other private and non-observable'. Exterior observation is neither sufficient to account for, nor to explain the actor's activity. It is important to consider his/her particular way of living, of perceiving, of making sense of his/her situation... to consider his/her own world. Approaching the subjective side of the practice enables us to study such practice. The difficulty lies in the fact that the subjective side of practice stems from an embodied meaning, from 'significant real-life sets' (Merleau-Ponty 1942, p.179), from knowing-in-action (Piaget 1974), and from cognition embedded in practice (Yanow \& Tsoukas 2007). Practice 'conveys an ante-predicative prelinguistic meaning' (Dauliach 1998, p.309), similar to 'pre-reflected awareness' (Vermersch 2003, p.71) or in Polanyi's words, a kind of subsidiary awareness. According to Taylor, Yanow \& Tsoukas (2007, p.10) point out that '[M]uch of our intelligent action in the world is carried on unformulated. It flows from an understanding which is largely inarticulate'. In spite of its unarticulated nature, it is important to address these constituents.

The third postulate concerns the actor: he/she is considered to be a reflective practitioner (Schön 1983). He/she is endowed with the possibility of recognising his/her own activity from a new perspective. The phenomenological premises underlining 'the power the subject has to set sights on himself/herself' (Merleau-Ponty 1988, p.408) establish the possibilities the actor has to explicate his/her experience (Dauliach 1998; Vermersch 2003, 2004). In other words, 'humans have the capacity to reflect on what they do and to articulate those reflections' (Yanow \& Tsoukas 2007, p.15). However, the actor is not spontaneously able to update it: to become aware of his/her own subjective experience, its descriptive thematisation, and even prior to all that, its deliberate reflection are not spontaneous, nor immediate, nor direct, nor easy!' (Vermersch 1999b, p.13). It is difficult 'to relate to something which has not yet become the object of conscious awareness' (Vermersch 1999a, p.34). Many authors who are interested in organisational knowledge, highlight this difficulty (c.f., Nonaka \& Tackeuchi 1995 or Tsoukas 2003). 'The knowledge people use in organizations is so practical and deeply familiar to them that when people are asked to describe how they do what they do, they often find it hard to express it in words' (Tsoukas 2003, p.413). 'If the subject wants to be able to produce a description he first has to presentify the lived experience which serves as the point of reference and to suspend his usual 
way of doing things in order that what previously only existed 'in act' now appears as object' (Vermersch, 1999a, p.36). If any actor is capable of reflection, it is not a position that is spontaneously adopted towards his/her own action. It should occur as soon as a surprise appears (Schön 1983), when there is a disturbance, an interruption (Patriotta 2004; Yanow \& Tsoukas 2007), but it can also, as we will see, be encouraged by a method (Theureau 1992; Vermersch, 1994). Usual verbalisations concerning the action stem more often from a discourse of rationalisation, or of justification than an explication. Indeed, as Lahire (2002, p.391), following Bourdieu (1972), emphasizes, during social interaction or sociological interviews, the actors are led to 'to talk about themselves and to select in their past the traits they judge to be salient'. Consequently, the discourse produced does not correspond to an explication, but is similar to a 'verbal construction of oneself by oneself [which] is the product of narrative work based on the observation of oneself by oneself and by others' (Lahire 2002, p.392). Informants tend to use abstract knowledge in order to describe their actions (Lave 1988). Accordingly, the method developed must constitute an aid to return to, to reflect on, the intended action and to verbalize such action. The method must enable 'the actor to accompany the researcher in what, during the practice, makes sense for former' (Rix et al. 2005, p.275). It must also incite the practitioners 'to re-view the situation they are in, to relate their circumstances in a different way' (Tsoukas 2003, p.424). This is done in order to inform the researcher what matters. To the extent that 'focusing on a subsidiary constituent of skilful action... changes the character of the activity one is involved with' (i.e., p.417) and disturbs it, this method takes place a posteriori.

The actor's return on his/her own activity consummates the passage from an act to a linguistic activity about this act. As Tsoukas (2003) argues, an epistemological break has taken place: knowing-in-action and discursive knowledge concerning it are not of the same nature. On one hand, as we have noted, knowing-in-action is only manifested in, by, and during action (Quéré 1998). Hence, their content can be deemed implicit insofar as it is not yet articulated. On the other hand, 'the activity exists independently of the exchange', of its reflection (Clot 1999, p.152); the discourse concerning it arises from another coupling between the actor and his/her environment (Maturana \& Varela 1994; Theureau 1992, 2006). This new action has its own objective, describing the first one, and its own organisation which necessarily introduces a succession, a logical link, between events that, at the time they take place, can be more or less identified as distinct phenomena, more or less concomitant, etc. Faced with the irreducibility of practice to a discourse, the researcher is confronted with a dilemma. Either he/she resigns him/herself to no longer taking action as a research object 
insofar as all scientific advancement proceeds from a discourse and insofar as practice does not need discourse about it in order to be efficient; or, while accepting the action's irreducibility and the impossibility for verbalisations to cover it, he/she tries to understand it by interesting him/herself in the relation that the verbalisations of the actor have to his/her actions. This second position is the one we adopt by working, as does Vermersch (1999a, p.35), on 'the controlled employment of reflecting activity'.

Finally, in order to avoid reducing a theory of action to a theory of a discourse of action (Ricoeur 1990), the necessity arises to use different sources of documentation of practices. The last postulate therefore concerns the interest of a triangulation: 'to understand and analyse the course of the action, [...] the verbalisations will come to complement the information brought by what is observable and the traces of fulfilled action" (Vermersch 2003, p.19). If our phenomenological orientation leads us to outline the insufficiency of observation to understand practice (Céfaï \& Depraz 2001), it seems important to criss-cross different kinds of data in order to approach embodied and tacit dimensions of practices.

\section{Presentation of the system}

To understand practices in their ordinary contexts, the method is founded on participant observation. This position directly follows Malinowski's (1944) ethnological methods. However, it is important to draw attention to the way that participant observation is implemented, and especially to consider the place and role of the researcher. The researcher does not intend to intervene in the actor's practices and devotes himself/herself to their investigation. If his/her participation in the activity only amounts to observing and following it in order to apprehend what is happening, it is not with the intention of covering, in a neutral and exhaustive manner, a "given reality". Furthermore, as Favret-Saada (1977) demonstrated, even the observer who wants to be an outsider, participates in the situation he/she is studying both through the way he/she regards it and the consideration the others have for him or her. During observation, the researcher stands in the background. On the one hand, this position allows him/her time to observe, to take notes in situ, as well as to implement different investigative systems. On the other hand, it prevents him/her from having to take sides with members of the group; in this way, he/she conserves the possibility of sharing a posteriori, during an interview, each actor's own experience without that actor feeling compared to or judged in relation to others. Indeed, insofar as the actors are invited, in turn, by the researcher to make their own situated experience explicit, the participant observation must also engender the possibility of this kind of exchange. Once the researcher has made sure that each member 
of the group participates voluntarily, and accepts both the research and his/her presence, participant observation enables him/her to build a trusting relationship with each actor. This trust-building is progressive. On one hand, the researcher must not jeopardise the project. On the other, the build-up of this trusting relationship depends on the perception that the subjects have of the researcher as well as of his/her intentions. Thus, it seems important to show to each person that the objective is in no way to judge or evaluate, but to learn and understand his/her practice.

During this participant observation, the researcher constitutes different types of observation data. Even if, as we have noted, this outside observation is not sufficient, it is essential to have, at the end, different kinds of data to document embodied and tacit dimensions of practices. Two kinds of video are recorded at the same time:

- one corresponds to an outside point of view of the subjects' activity filmed from a broad perspective using a digital video camera (the objective camera); and

- the other is made using a video camera with a lens $(\varnothing 8 \mathrm{~mm})$ fixed on the glasses of the actor or on an ear piece (the subjective camera), and with a microphone ( $\varnothing 6 \mathrm{~mm})$ attached to his/her clothes. This video camera and microphone are linked to a mini DV recorder $(73 / 37 / 112 \mathrm{~mm}$ for $340 \mathrm{~g})$ that is placed in a coat pocket or on a belt. This set-up enables the recording of the situated subjective perspective of the actor during his/her practice. We do not assimilate this perspective, as do some authors (Lahlou 1999, 2006), to the actor's perception, to his/her 'phenomenal visual and auditory flux' (Lahlou 2006, p.213). It represents a trace of the activity that is close to the actor's visual field in situ.

As we have indicated, to understand practices and what is underlying them, it is important to approach the implicit, personal, and significant side of the action, beyond these traces of the activity. To that end, and regarding the need to control the reflecting process, we designed a system that incites and helps the actor to explicate his/her practices. In this way, several systems have been developed: the explication interview (Vermersch 2003); auto confrontation in Von Cranach \& Kalbermatten's work (1982); auto confrontation as part of the course-of-action theory (Theureau 1992, 2006); or in a Vygotskyian perspective, a crisscross auto confrontation (Clot 1999), and so on. As far as we are concerned, we use the recording of the situated subjective perspective during a subjective re situ interview. This interview takes place as soon as possible after the practice. It mobilises the situated subjective perspective by starting at the beginning of the recording; it begins by requesting the actor to talk, in as much detail as possible, about what he/she experienced during the event 
that the video is showing. Throughout the interview, watching the video enables the actor to be focused, accompanied, and brought as close as possible to the dynamics of his/her actions. It, thus, helps him/her to make his/her experience explicit. Using this video recording as a way to support the interview presents the advantage of focusing the dialogue on the singular and effective course of a specified practice. It defines a particular occurrence of the activity studied by materialising it. In order to explicate of the action, this perspective seems to facilitate the actor's effort of reflection as much as the conducting of the interview by the researcher. Indeed, the trace interposed between the actor and his/her action, the trace that objectifies it, seems close to the way in which he/she actually could have perceived the situation in which he/she acted. Thus, the subjective re situ interview proceeds from ' $a$ double steering of the actor's reflection, by the recorded trace and the dialectical orientation of words' (Rix \& Biache 2004, p.392). This interview therefore favours a sharing of the experience that allows the researcher to understand what makes sense for the actor at the moment he/she acts, to approach the subjective side of his/her practice: he/she, 'by drawing our attention to certain things, makes us "see connections", (Tsoukas 2003, p.424).

Three different kinds of data emanate from this system: videos of an actor's situated subjective perspectives during his/her practice, videos of his/her behaviour, and subjective re situ interviews. The first two, once the interview is completed, represent signs of the practice in its effective completion; the third one, once transcribed, gives meaning to the practice thanks to the actor's explications. By taking the actor's phenomenal experience into account, we thus attempt to formalise part of practical knowledge.

\section{An investigation of adaptive practices of an expert polar explorer}

In this third section, we present the way in which this method was set up within a research program whose purpose is to study 'in vivo', or close-up, an expert's practices in extreme, that is evolving, uncertain, and risky, situations in order to derive theoretical propositions (Pettigrew 1990). Close to Lazarus's research (1999), we work on the adaptation practices that actors use to cope with situations. The choice of polar expeditions as a research context is a result of precise theoretical and methodological concerns that have been addressed in other papers and will not be developed here (cf. Lièvre 2004a, 2004b; Lièvre \& Rix 2007). We should only point out that the nature of this extreme context, paradoxically, greatly facilitates the researcher's work. The choice of this environment eliminates various problems such as the acceptance of the researcher in the field and obstacles related to secrecy and confidentiality. We are not dealing with a private company in cut throat competition, but with 
groups, without legal status, that bring together voluntary enthusiasts. The issue of secrecy is not viewed in the same way. Moreover, there is a tradition in polar expeditions, even those specifically focused on athletic performance, to integrate a scientific dimension. The researcher's request is therefore welcomed with pleasure by the actors who quite often solicit and demand such participation themselves. Furthermore, the continuous nature of the activity - preparing outings that last several days, expeditions in the field that can last up to two months - creates proximity of the researcher and the actors concerned that facilitates trust. Finally, in this context, the practical logic of the actors is pushed to its limits that in turn make this logic more visible for the researcher.

As an illustration, we explain how this method was set up during the expedition 'Nunavut 2003 ' in order to understand the adaptive practices of an expert to cope with extreme situations. In particular, we ask about the way in which risk emerges for him as it happens. First of all, we specify the kind of participant observation carried out during the expedition, and then discuss the data.

The researcher joins the team as an person inexperienced in ski polar exploration, as an individual who wants to learn others' practices, and as an observer who follows the group wherever it goes and participates in all collective tasks without taking responsibility or decisions. This ethnographic work begins with the idea of the project, continues through the different phases of preparation and realisation, and ends with the return home. In this way, the researcher participates in all the activities of the small expedition group.

During this trek, at different critical phases, the expedition leader, Michel, who, after more than 30 years of expeditions, is recognised by his peers as an expert in polar expeditions, was equipped with the subjective camera. The researcher, while walking, filmed his behaviour from the side using the objective camera. The subjective re situ interviews took place in France after the trek.

We present, in a table, the data about a moment of Michel's progression. In the first column, we describe the context using video recordings of Michel's behaviour and his situated subjective perspective. The idea is to expose what can be seen and/or heard at that moment while limiting the interpretative intrusions. This description is not intended to be exhaustive: it is still possible to clarify Michel's behaviour and events. It does, however, inform what actually happened, enabling anyone who does not have the videos and did not experience this moment of progression, to follow the course of the practice. In the second column, part of the subjective re situ interview about the same moment is re-transcribed; it is through this dialogue that the researcher can little by little approach what the explorer 
experiences, what is significant for him at that moment, what compels him, what affects him, what matters to him, etc. With these different data, we attempt to formalise Michel's practice at that particular moment of progression, while taking into consideration both his experience through his explications and what he actually did. Thus, this formalisation results from a synthesis of descriptive data and verbalisations. It is the researcher's narrative construction which presents the course of Michel's practice, especially how the situation becomes for him, as he progress, risky. It describes step by step what Michel is doing and what is making sense for him as it happens. 
Table 1 : Illustration of different kinds of data : a formalisation of a practice

\begin{tabular}{|c|c|}
\hline Description of the context & Explanation of the actor \\
\hline $\begin{array}{l}\text { He stops and points to the right bank with his stick, and } \\
\text { as I arrive next to him, he says: 'You see, these are } \\
\text { crappy areas because you can have a bear hiding out } \\
\text { inside there that suddenly comes out...' } \\
\text { Then starting to walk and looking at his fellow team } \\
\text { members, he continues: 'That's why I told them to not } \\
\text { stay in front of the gun, but... They didn't listen to me.' } \\
\text { He continues to walk towards the end of the fjord and } \\
\text { looks frequently just in front of him, at the other team } \\
\text { members and the coast. }\end{array}$ & $\begin{array}{l}\text { Researcher: So, you're looking for something in } \\
\text { particular... } \\
\text { Michel: Here, I'm looking at the coast... } \\
R: \text { For you, there is danger there? } \\
M: \text { The danger is on the coast... } \\
\text { R: Ok... Is it a risk, is it danger, what is it at that } \\
\text { moment? } \\
M: \text { There is a risk, not in... which is not } \\
\text { inconsiderable... I know that at this spot there is a den, } \\
\text { that there are dens because I've seen them... I know } \\
\text { there's a seal that got itself killed, I know because there } \\
\text { are bear tracks... So there are all the indications that } \\
\text { point to... } \\
R: \text { So you're telling me that, at that moment, that's what } \\
\text { really matters? } \\
M: \text { You see, I'm saying it again... } \\
R: \text { Does that bother you there? That they [the other } \\
\text { team members] didn't listen to you? Are you saying it } \\
\text { to me again?... } \\
M: \text { No, it doesn't bother me, but I'm saying, they're } \\
\text { wrong... } \\
R: \text { Ok... } \\
M: \text { You see, I'm saying, that is the kind of crappy area } \\
\text { for those reasons... I'm telling them not to do it, to not } \\
\text { stay in front of me, they stay in front, let them go to } \\
\text { hell! }\end{array}$ \\
\hline \multicolumn{2}{|c|}{ Formalisation of the practice } \\
\hline $\begin{array}{l}\text { At the end of this fjord, Michel knows there are bears: h } \\
\text { and the remains of a seal confirm this possibility. While } \\
\text { behind a block of ice: we might see it at the last second, } \\
\text { gun is on Michel's pulka. For everyone's safety, it's bett } \\
\text { mentioned that to everyone, but the others continue to st } \\
\text { own pace, he remains attentive. }\end{array}$ & $\begin{array}{l}\text { already seen dens at this spot. The tracks in the snow } \\
\text { alking on, he is on the lookout. A bear can be hidden } \\
\text { when he charges. You have to be ready to react. The } \\
\text { to stay in a group and behind the gun. Michel } \\
\text { in front, which annoys him. While walking at his }\end{array}$ \\
\hline
\end{tabular}


With this kind of data, we are able to work on how the risks associated with the presence of bears are actualised during the course of the expert's practice. During the moment studied, Michel perceived a threat and wanted the members of the expedition to line up behind him as a safety measure. This example allows us to reveal several particular elements that make sense for Michel in this situation and which led him to perceive the risk of a bear. In this case, he noted: bear tracks, dens seen during a previous trek, seal remains, geographic layout. The emergence of the risk is based on a network of constituents which are only meaningful and salient as regards to knowledge, previous experience, and his own involvement. Even if before the trek, Michel planned procedures in order to cope daily with this danger during the expedition, for example, protection from the bear during the night, management of the group's progress, and so on, in the real-life situations, this risk was not permanent, it did not exist en-soi. As a result, in reality, more often than not procedures were not followed.

Firstly, as polar explorers often use other expeditions' log books in order to prepare and succeed in their project, this kind of formalisation of practice could provide an interesting tool within this community.

Secondly, in order to study how risks emerge for expedition leaders and their adaptive practices to cope with them, we formalise their practices during several moments. Then, we analyse these different formalisations in order to characterise the process during which the risk is constructed. We consider foremost:

-how past experiences contribute to risk determination processes;

-the sensitivity of the expert which determines how "things are [...] encountered [...] as attractive, threatening, interesting, boring, frustrating, etc" (Dreyfus, in Yanow \& Tsoukas 2007, p.18), for him in one situation at one time;

-if, when and how the construction of a situation as risky becomes shared by the whole group; -places/functions of objects, techniques, planned procedures in this process.

This kind of analysis allows us, for example, to theorise relationships between previous risks, planned procedures, the emergence of risks during the course of the expert's practice, and actions undertaken to cope with the dangers. It seems to shed new light on the conception and management of organisations confronted with extreme situations.

\section{Conclusion}

To conclude, we highlight, firstly, the importance and the use of this kind of data in knowledge management; secondly, we point out the limits of such results and directions of further researches. 
The methodology discussed has proved to be an interesting tool to document practical knowledge: it enables researchers to understand a posteriori what, in a particular context of activity, makes sense for experienced actors. We conclude by highlighting three reasons why this method is of particular interest. Firstly, this method could also be used by an engineer or a manager to gain a better understanding of a particular activity, seeing that several researchers (Lalhou 1999; Theureau 2006) have already used a similar method in order to study the activity of executives or operators in traditional organisations. Secondly, as this method results in the formalisation of practice, it offers a real opportunity to test the usefulness of this kind of description within knowledge management practices. In effect, in order to know if "the explicit knowledge created by "tacit knowledge explication" facilitates reproduction of the behaviours attributed to tacit knowledge' (Gourlay 2006, p.65) and how this kind of description can be used within knowledge management practices, we have first to construct it. In this way, the methodology discussed is a contribution to knowledge management. Thirdly, these kinds of data allow for the theorisation of relationships between prescriptions/plans and the real activity of an expert: it opens up new perspectives on the conception and management of organisations, especially those confronted with extreme situations. Moreover, research, close to Berkeley group, on high reliability organisations underline the importance of descriptions of effective and situated practices (Bourrier 2001; Journé \& Raulet-Crozet 2008; Roberts 1990; Weick et al 1999).

We are only able to touch upon the possibilities for an organisation to use a formalisation of practice. Even if, we, like Tsoukas (2003), believe that practical knowledge can neither be transferred, nor transmitted directly, this kind of description could constitute a tool within a community of practices. Several authors underline also the relevance of narratives in knowledge management (cf. Patriotta 2003, 2004). However, in order to evaluate the importance and the use of this formalisation of practice within knowledge management, new studies are necessary. Several directions could be developed in order to research the relevance of such formalisation in organisations: during a design process (Béguin 2007), during more or less formal communications between colleagues or as an artefact for actor himself. Finally, as we focus on the personal characteristics of practical knowledge, another line of further research could be the collective side of activity. Insofar as the amount of personal practical knowledge is not sufficient to operate an organisation, to understand knowledge processes and systems supposes investigation on a collective scale. 


\section{References}

Béguin P (2007) Taking activity into account during the design process. @ ctivités 4(2), 115121.

Bourdieu P (1990) The logic of practice. Stanford University Press, Stanford.

Bourrier M (2001) Organiser la fiabilité. L'Harmattan, Paris.

Brown JS and Duguid P (1991) Organizational learning and communities-of-practice: toward a unified view of working, learning, and innovation. Organization science 2, 40-57.

Céfaï D and Depraz N (2001) De la méthode phénoménologique dans la démarche ethnométhodologique. In L'ethnométhodologie. Une sociologie radicale (De Fornel $\mathrm{M}$, Ogien M and Quéré L), pp 99-119, La Découverte, Paris.

Clot Y (1999) La fonction psychologique du travail. PUF, Paris.

Cook SDN and Brown JS (1999) Bridging epistemologies: the generative dance between organizational knowledge and organizational knowing. Organization Science 10, 381-400.

Dauliach C (1998) Expression et onto-anthropologie chez Merleau-Ponty. In Merleau-Ponty. Notes de cours sur l'origine de la géométrie de Husserl, suivi de Recherches sur la phénoménologie de Merleau-Ponty (Barbaras R, Ed), pp 305-330, PUF, Paris.

De Fornel M and Quéré L (1999) La logique des situations. EHESS, Paris.

Favret-Saada J (1977) Les mots, la mort, les sorts. Gallimard, Paris.

Foray D (2004) The economics of knowledge. MIT Press, Cambridge.

Garfinkel H (1967) Studies in ethnomethodology. Prentice hall, New Jersey.

Goody J (1977) The domestication of savage mind. Cambridge University Press, Cambridge.

Gourlay S (2006) Towards conceptual clarity for 'tacit knowledge': a review of empirical studies. Knowledge Management Research \& Practice 4, 60-69.

Hansen MT, Nohria N and Tierney T (1999) What's your strategy for managing knowledge? Harvard Business Review 77, 106-116.

Hutchins E (1995) Cognition in the wild. MIT press, Cambridge.

Journé B and Raulet-Croset N (2008) Le concept de situation : contribution à l'analyse de l'activité managériale dans un contexte d'ambiguïté et d'incertitude.M@n@gement 11(1), 27-55.

Lahire B (2002) Portraits sociologiques. Dispositions et variations individuelles. Nathan, Paris.

Lahlou S (1999) Observing cognitive work in offices. In Cooperative buildings. Integrating information, organizations and architecture (Streitz N, Siegel V, Hartkopf V and Konomi S, Eds), pp 150-163, Springer, Heidelberg. 
Lahlou S (2006) L'activité du point de vue de l'acteur et la question de l'intersubjectivité. Communication 80, 209-234.

Lam A (2000) Tacit knowledge, organizational learning and societal institutions: an integrated framework. Organization Studies 21, 487-513.

Latour B (2005) Re-assembling the social. An introduction to actor-network theory. Oxford University Press, Oxford.

Lave J (1988) Cognition in practice: Mind, mathematics, and culture in everyday life. Cambridge University Press, New York.

Lazarus RS (1999) Stress and emotion. A new synthesis. Springer, New York.

Lièvre P (2004a) Vers un savoir d'action en sciences de gestion : le cas des expéditions polaires. Gérer et Comprendre 75, 4-18.

Lièvre P (2004b) La logistique en milieux extrêmes : le cas des expéditions polaires. In La logistique entre management et optimisation (Lièvre P and Tchernev P, Eds), pp 149-156, Paris, Hermés-Lavoisier.

Lièvre P and Rix G (2007) Vers la construction d'un observatoire de l'effectivité organisationnelle, une illustration à partir d'une investigation d'une expédition polaire. In Proceedings of international conference on Innovative research methods to create valid and operational knowledge (Savall H, Bonnet M, Zardet V, Péron M, Eds), p561, ISEOR, Lyon, France.

Malinowski BK (1944) A scientific theory of culture and other essays. Oxford University Press, New York.

Maturana HR and Varela FJ (1994) L'arbre de la connaissance. Editions Addison-Wesley France, Paris.

Merleau-Ponty M (1942) La structure du comportement. PUF, Paris.

Merleau-Ponty M (1988) Merleau-Ponty à la sorbonne. Résumé de cours 1949-1952. Cynara, Dijon-Quetigny.

Nonaka I and Tackeuchi H (1995) The knowledge-creating company. Oxford University Press, New-York.

Orlikowski WJ (2002) Knowing in practice: enacting a collective capacity in distributed organizing. Organization science 13, 249-273.

Orr J (1996) Talking about machines: an ethnography of a modern job. ILR Press, Ithaca, NY.

Patriotta G (2003) Sensemaking on the shop floor: Narratives of knowledge in organisations. Journal of Management Studies 42, 349-375. 
Patriotta G (2004) On studying organizational knowledge. Knowledge Management Research \& Practice 2, 3-12.

Pettigrew AM (1990) Longitudinal field research on change: theory and practice. Organization Science 1, 267-292.

Piaget J (1974) Réussir et comprendre PUF, Paris.

Polanyi M (1996) The tacit dimension. Harper Torchbooks, New-York.

Quéré L (1998) La cognition comme action incarnée. In Sociologie et connaissance: Nouvelles approches cognitives (Borzeix A, Bouvier A and Pharo P, Eds), pp 143-164, CNRS, Paris.

Ricoeur P (1990) Soi-même comme un autre. Seuil, Paris.

Rix G (2006) Pour un meilleur positionnement du Dire par rapport à l'Agir. In L'activité à projet dans tous ses états (Lièvre $\mathrm{P}$, Lecoutre $\mathrm{M}$ and Kaba Traoré M, Eds), pp 82-97, Hermes, Paris.

Rix G and Biache M-J (2004) Enregistrement en perspective subjective située et entretien en re situ subjectif: une méthodologie de constitution de l'expérience. Intellectica 38, 363-396.

Rix G, Récopé M and Lièvre P (2005) Etude anthropologique des pratiques des expéditeurs polaires à ski : une approche du corps agissant et vécu. In Le corps de l'alpin. Perceptions, représentations, modifications (Boëtsch G, Ed), pp 271-283, Editions des Hautes Alpes, Gap.

Roberts KH (1990) Managing high reliability organizations. Californian management revue 32/4, 101-113.

Schön DA (1983) The reflective practitioner. Basic books, New York.

Suchman L (1987) Plans and situated actions. The problem of human-machine communication. Cambridge University Press, Cambridge.

Theureau J (1992) Le cours d'action, analyse sémiologique : essais d'une anthropologie cognitive située. Peter Lang, Berne.

Theureau J (2006) Le cours d'action: méthode développée. Octares, Toulouse.

Tsoukas H (1996) The firm as a distributed knowledge system: a constructionist approach. Strategic Management Journal 17, 11-25.

Tsoukas H (2003) Do we really understand tacit knowledge? In The Blackwell handbook of organizational learning and knowledge management (Easterby-Smith M and Lyles MA, Eds), pp 410-427, Blackwell Publishing Ltd, Oxford.

Vermersch P (1994) L'entretien d'explicitation. ESF, Paris.

Vermersch P (1999a) Introspection as practice. Journal of consciousness studies 6, 17-42. 
Vermersch P (1999b) Pour une psychologie phénoménologique. Psychologie française 44, 718.

Vermersch P (2003) L'entretien d'explicitation. Nouvelle édition enrichie d'un glossaire. ESF, Paris.

Vermersch P (2004) Prendre en compte la phénoménalité : propositions pour une psycho phénoménologie. Expliciter 57, 35-45.

Von Cranach M and Kalbermatten U (1982) Ordinary interactive action: theory, methods and some empirical findings. In The analysis of action. Recent theorical and empirical advances (Von Cranach M and Harré R, Eds), pp 115-160, Cambridge University Press, Cambridge.

Weick K, Sutcliffe K and Obstfeld D (1999) Organizing for High reliability: Processes of collective Mindfulness. Research in Organizational Behavior 21, 81-123.

Yanow D and Tsoukas H (2007) Acquiring expertise in professional practice: reflecting on the role of reflection-in-action. Wageningen University Communication Science Seminar Series 2006-2007 [WWW document] http://www.cis.wur.nl/NR/rdonlyres/9042CA859F3C-4E87-A1E7-5A5F7AAA6B39/35366/DvoraYanow_paper.pdf (accessed 02 April 2008) 


\title{
Acknowledgements
}

Our thanks to Georgiana Wierre-Gore (Blaise Pascal University, UFR STAPS, ClermontFerrand) and David Maker (Graduate School of Management, Groupe ESC ClermontFerrand) for their careful reading.

\begin{abstract}
About the authors
Géraldine Rix is a Lecturer at Blaise Pascal University (Clermont-Ferrand, France), and a member of the research group Corporeal experience and practices of the PAEDI. She studies the embodied dimensions of practices, especially the those of polar expeditions and of refereeing situations, and has developed a patented new methods to make these dimensions of human experience explicit. She has contributed to the following collection, La construction de savoirs pour l'action, in 2007, and to several reviews: Intellectica, ${ }^{\circ} 38$, in 2004 or Science et Motricité, ${ }^{\circ} 56$, in 2005.
\end{abstract}

Pascal Lièvre holds a $\mathrm{PhD}$ in Production Economics from the University of Lyon-II, he is senior lecturer (HDR, University of Aix-Marseille-II) in Management Science at the IUP de Management of Clermont-Ferrand, University of Auvergne. He has been a lecturer in Logistics to Graduate and Postgraduate students since 1996. He also works as a researcher for the CRET-LOG in Aix-en-Provence, and for the Centre de Recherche Clermontois de Gestion et de Management. Since 2000, he has been in charge of a research program into the logistics of extreme situations dealing mainly with polar expeditions. He has directed or co-directed five books on logistics, amongst which in 2006, Management de projet, les règles de l'activité à projet (ed. Hermes \& Lavoisier), in 2007, La Logistique (ed. La découverte). 